\title{
Phylogeny of the coral genus Plesiastrea (Cnidaria, Scleractinia)
}

\author{
Francesca Benzoni ${ }^{1,2,4}$, Roberto Arrigoni ${ }^{2}$, Fabrizio Stefani ${ }^{2}$, Michel Pichon ${ }^{3}$ \\ ${ }^{1}$ Institut de Recherche pour le Développement, UMR227 Coreus2, 101 Promenade Roger Laroque, BP A5, 98848 \\ Noumea Cedex, New Caledonia \\ ${ }^{2}$ Dept. of Biotechnology and Biosciences, University of Milano-Bicocca, Piazza della Scienza 2, 20126 Milan, Italy \\ ${ }^{3}$ Museum of tropical Queensland, Townsville 4810, Australia \\ ${ }^{4}$ E-mail: francesca.benzoni@unimib.it
}

Key words: COI, Plesiastrea versipora, Plesiastrea devantieri, rDNA, robust clade

\begin{abstract}
Until coral molecular phylogenies were published, the genus Plesiastrea was traditionally part of the family Faviidae and considered by several authors to be closely related to the genus Montastraea. However, genetic data has shown that Plesiastrea versipora, the genus type species, is evolutionarily distinct within the Robust clade of the Scleractinia and does not belong to the large clade grouping most representatives of the families Faviidae, including Montastraea, Mussidae, Merulinidae, Trachyphylliidae, and Pectiniidae. Instead, $P$. versipora is closely related to non reef-dwelling taxa currently ascribed to the Oculinidae (Cyathelia axillaris) and Caryophylliidae (Trochocyathus efateensis). However, no discussion on the morphologic features of $P$. versipora compared to other taxa has been published yet. Moreover, no information is available about the phylogenetic placement of Plesiastrea devantieri, the only other species in the genus. The phylogeny of both Plesiastrea species was addressed through molecular analyses (COI and rDNA) and morphological analysis. Morphological differences between the two species included number of septa, cycles of vertical structures in front of the septa and septal micromorphology. On the basis of these data and nuclear and mitochondrial markers, $P$. devantieri belongs to the Faviidae-Merulinidae-Pectiniidae-Trachyphylliidae clade (Clade XVII sensu Fukami et al., 2008) and is most closely related to Goniastrea aspera and G. palauensis. The type species of the genus Goniastrea, G. retiformis, however, is not closely related to either G. aspera and G.palauensis, or to P. devantieri. Taxonomic implications of these findings and morphologic affinities between the two species and closely related taxa are discussed.
\end{abstract}

\section{Contents}

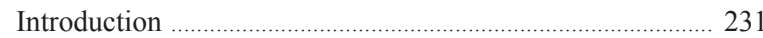

Material and methods ……………………………………….... 233

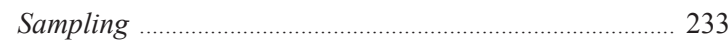

Specimen identification ......................................................... 235

Museum collections and other examined specimens ....... 235

Morphologic analyses ......................................................... 235

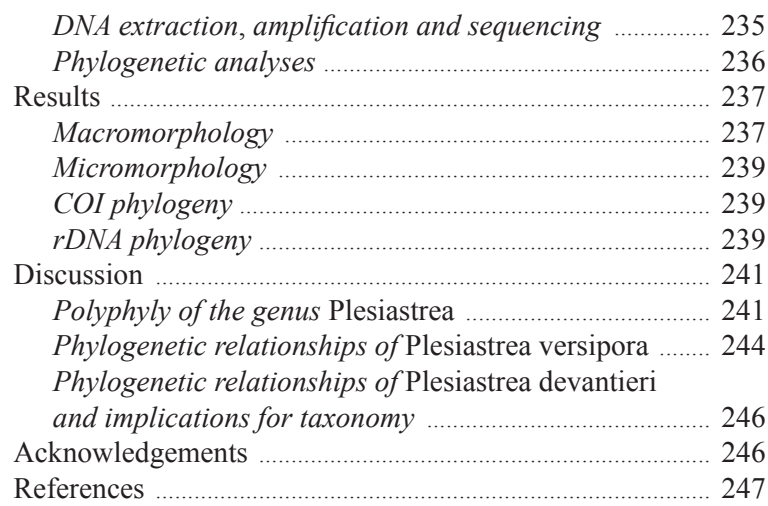

\section{Introduction}

Scleractinian corals (Cnidaria, Scleractinia) belong to two main molecularly defined clades (Romano and Palumbi, 1996), the Robust and the Complex clade, and most families and genera as traditionally defined on the basis of skeleton macromorphologic characters are polyphyletic (Fukami et al., 2004, 2008; Benzoni et al., 2007; Nunes et al., 2008; Huang et al., 2009, 2011; Kitahara et al., 2010a). Moreover, Kitahara et al. (2010a) recently showed that azooxanthellate solitary corals from deep-water form a clade basal to both the Robust and the Complex corals. In other words, molecular phylogenies of scleractinian corals and traditional taxonomy and systematics based on skeleton morphology are, to a large extent, incompatible. Reconciliation of these two approaches is ongoing, but presently the need for an integrative approach which includes molecular, macrostructural, microstructural, reproductive and ecological analyses is required (Budd and Stolarski, 2009; Budd et al., 2010). In addition, 
shallow water, deep water, colonial, solitary, tropical and temperate taxa should all be included in the analyses to determine the evolutionary history of this ancient group (Romano and Cairns, 2000; Le Goff-Vitry et al., 2003; Barbeitos et al., 2010; Kitahara et al., 2010b).

One of the most challenging tasks in the taxonomy of the shallow water zooxanthellate corals is the revision of the family Faviidae Gregory, 1900 which, together with the Merulinidae Verrill 1866, Mussidae Ortmann, 1890, Trachyphyliidae Verrill, 1901, and Pectiniidae Vaughan and Wells, 1943, are found in the Robust clade (Fukami et al., 2004, 2008; Kitahara et al., 2010b). Despite a deep divergence between Atlantic and Indo-Pacific taxa in both the Mussidae and Faviidae (Fukami et al., 2004), most genera from these families were retrieved in several closely related clades. The genera Cladocora Ehrenberg, 1834, Oulastrea Milne-Edwards and Haime 1848, Leptastrea MilneEdwards and Haime 1848, and Plesiastrea Milne-Edwards and Haime 1848, however, are not closely related to the remainder of the Faviidae, nor to one another (Fukami et al., 2008; Barbeitos et al., 2010). Plesiastrea is clearly distinct and divergent from the rest of the Faviidae (Fukami et al., 2008). Despite strong morphologic affinities (Vaughan and Wells, 1943; Wells, 1956; Chevalier, 1971; Wijsman-Best, 1977; Veron et al., 1977; Chevalier and Beauvais, 1987), no close phylogenetic relationship has been found between Plesiastrea and the genus Montastraea de Blainville, 1830, the latter actually being polyphyletic (Fukami et al., 2004, 2008; Huang et al., 2009).

Different vertically developed skeletal structures are found in the corallites of scleractinian corals. Their origin, structure, number, size, and shape have been used for taxonomy and systematics (Vaughan and Wells, 1943). The principal ones are the septa (radially arranged around the centre of the corallite) and, if present, the columella (found at the centre of the corallite) (Vaughan and Wells, 1943; Chevalier and Beauvais, 1987). In certain taxa a third type of vertical skeletal structure can exist between the inner margin of the septa and the columella. These, generally referred to as palar structures (PS), are arranged in one or more crowns surrounding the columella. In transverse section PS can be of different shape and size within the same corallite. Their origin and the process of formation can be different. The term palus (pali) is used to refer to a pillar-like palar structure composed of its own system of divergent centers of rapid accretion (Stolarski, 2003) (formerly trabeculae), while a pali- form lobe is a PS formed by a single center of rapid accretion stemming from the inner end of a septum (Chevalier and Beauvais, 1987).

The genus Plesiastrea was originally described by Milne-Edwards and Haime (1848) on the basis of a specimen from the Indian Ocean named Astrea versipora by Lamarck (1816). The main characters of the genus were described as plocoid corallites, presence of pali sensu stricto, and the extracalicinal mode of corallite budding. The species Plesiastrea urvillei MilneEdwards and Haime, 1849, and P. quatrefagiana Milne-Edwards and Haime, 1849, were also ascribed to the genus but both may be junior synonyms of $P$. versipora (Veron et al., 1977). According to Chevalier (1971) the main skeletal character distinguishing Plesiastrea from the other genera is the presence of pali as opposed to paliform lobes in the other Faviidae such as, among the others, Montastraea and Goniastrea. Plesiastrea has presumably remained monotypic for decades until the description of $P$. devantieri on the basis of specimens from Socotra Island, Yemen (Veron, 2000, 2002). In his original description Veron (2002) did not provide details on the micromorphological characters of $P$. devantieri and species phylogenetic relationships were not examined.

Morphological affinities between Plesiastrea and Montastraea and nomenclatural confusion between the two taxa and Orbicella, a junior synonym of Montastraea (Wijsman-Best, 1977) on the one hand, and Favia on the other hand, have been discussed by Wijsman-Best (1977) and Veron et al. (1977) who provided detailed accounts of the history of nomenclatural confusion between those genera. Although Plesiastrea is superficially similar to Cyphastrea (Veron, 2002) no nomenclatural confusion occurred between the two taxa. Chevalier (1971) described transitional morphs between $P$. versipora and $M$. curta. The latter species was first ascribed to Orbicella by Dana (1846) and later moved to the genus Montastraea whose type species, Astrea guettardi Defrance, 1830, is a fossil. According to Wijsman-Best (1977) some specimens identified as Orbicella by Yabe et al. (1936) would actually belong to Plesiastrea while specimens identified by Wells (1954) as Plesiastrea would belong to Montastraea. Moreover, Wijsman-Best (1977) recognised transitional forms between $P$. versipora and another Montastraea species, M. annuligera (cf. holotype illustrated in Veron et al., 1977, p. 141, Fig. 267). Vaughan and Wells (1943) in their description of the genus, indicated that Plesiastrea was like Favia, but with extracalicinal budding, as opposed to intracalici- 
nal. It was Chevalier (1971) who finally suggested that the presence of true pali instead of paliform lobes and the absence of directive mesenteries would be sufficient to separate Plesiastrea from any species ascribed to the genus Montastraea. Later, molecular data supported this separation (Fukami et al., 2004).

No close relative of Plesiastrea versipora was apparent until Kitahara et al. (2010b) included several azooxanthellate and deep water taxa in their phylogenetic analyses of the Scleractinia. In their COI phylogeny a close phylogenetic relationship between $P$. versipora and Trochocyathus efateensis Cairns, 1999 (traditionally in the Caryophylliidae Dana, 1846) and $C y$ athelia axillaris (Ellis and Solander, 1786) (currently in the Oculinidae Gray, 1847) was suggested. To date, no morphological analyses have been performed to revise the micro-morphology of $P$. versipora in light of these molecular results. Finally, the phylogenetic relationships between $P$. versipora and $P$. devantieri Veron, 2002 have not been investigated.

In this paper morphologic and molecular analyses of $P$. versipora and $P$. devantieri were performed to ascertain the phylogenetic relationships, first, between the two congeneric species, and, second, with the Faviidae in general.

\section{Material and methods}

\section{Sampling}

Sampling took place at several localities in the Indian Ocean and Gulf of Aden (Table 1). Specimens of Plesiastrea versipora for morphological and molecular analyses were sampled along the Gulf of Aden coasts of Yemen, in Socotra and Mayotte. Plesiastrea devantieri was sampled in Socotra (type locality) and in Mayotte. The Goniastrea retiformis (Lamarck, 1816) and Montastraea curta (Dana, 1846) specimens included in the molecular analyses and illustrated in Fig. 1 were collected in Balhaf, Yemen, and Socotra, respectively. Sampling in Yemen and Socotra was performed between 2007 and 2010 within the frame of the Yemen Scleractinia Biodiversity Project supported by TOTAL SA.

Table 1. List of the material collected for this study and housed at the University of Milano-Bicocca (UNIMIB) collection. BI = Bir Ali (Gulf of Aden, Yemen); SO = Socotra Island (Indian Ocean, Yemen); KA = Kamaran Island (Red Sea, Yemen); MY = Mayotte Island (Indian Ocean, France); FB = F. Benzoni; MP = M. Pichon; SM = S. Montano; AC = A. Caragnano.

\begin{tabular}{|c|c|c|c|c|c|}
\hline UNIMIB code & Genus & species & collector & rDNA & $\mathrm{COI}$ \\
\hline BAL 178 & Plesiastrea & versipora & $\mathrm{FB}, \mathrm{MP}$ & & \\
\hline BAL 214 & Plesiastrea & versipora & $\mathrm{FB}, \mathrm{MP}$ & & \\
\hline Y719 & Plesiastrea & versipora & $\mathrm{FB}$ & FR837995 & FR837985 \\
\hline MU010 & Plesiastrea & versipora & $\mathrm{FB}, \mathrm{MP}$ & & \\
\hline MU111 & Plesiastrea & versipora & $\mathrm{FB}, \mathrm{MP}$ & & \\
\hline MU146 & Plesiastrea & versipora & $\mathrm{FB}, \mathrm{MP}$ & FR837996 & FR837986 \\
\hline MU169 & Plesiastrea & versipora & $\mathrm{FB}, \mathrm{MP}$ & & \\
\hline BA123 & Plesiastrea & versipora & $\mathrm{FB}, \mathrm{SM}$ & FR837994 & FR837984 \\
\hline AD021 & Plesiastrea & versipora & $\mathrm{FB}, \mathrm{MP}$ & & \\
\hline KA124 & Plesiastrea & versipora & $\mathrm{FB}, \mathrm{AC}$ & & \\
\hline SO115 & Plesiastrea & versipora & $\mathrm{FB}, \mathrm{MP}$ & & \\
\hline MY343 & Plesiastrea & versipora & FB & & \\
\hline SO024 & Plesiastrea & devantieri & $\mathrm{FB}, \mathrm{MP}$ & FR837997 & FR837987 \\
\hline SO031 & Plesiastrea & devantieri & $\mathrm{FB}, \mathrm{MP}$ & FR837998 & FR837988 \\
\hline SO093 & Plesiastrea & devantieri & $\mathrm{FB}, \mathrm{MP}$ & FR837999 & FR837989 \\
\hline MY003 & Plesiastrea & devantieri & $\mathrm{FB}$ & & \\
\hline MY004 & Plesiastrea & devantieri & FB & & \\
\hline MY053 & Plesiastrea & devantieri & FB & & \\
\hline MY064 & Plesiastrea & devantieri & FB & & \\
\hline MY139 & Plesiastrea & devantieri & FB & & \\
\hline SO041 & Montastraea & curta & FB & FR838000 & FR837990 \\
\hline BA024 & Goniastrea & retiformis & $\mathrm{FB}, \mathrm{SM}$ & FR837991 & FR837981 \\
\hline ВА077 & Goniastrea & retiformis & $\mathrm{FB}, \mathrm{SM}$ & FR837992 & FR837982 \\
\hline SO070 & Goniastrea & retiformis & $\mathrm{FB}, \mathrm{MP}$ & FR837993 & FR837983 \\
\hline
\end{tabular}


Type material
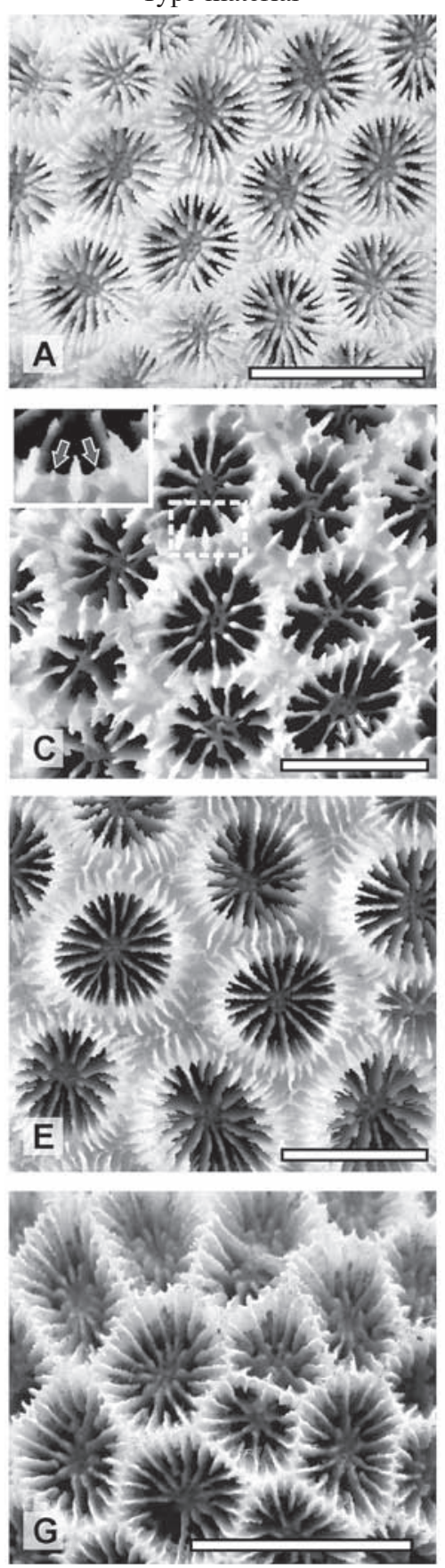

Examined material
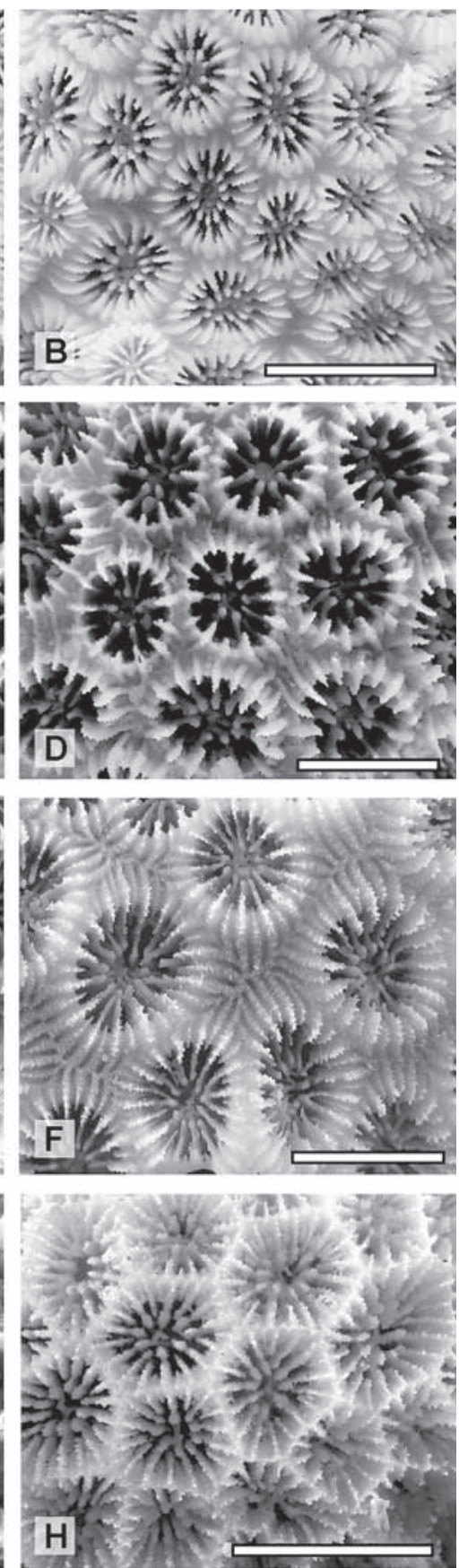

Fig. 1. Morphology of type material and examined specimens of: Plesiastrea versipora A) holotype MNHN 36, and B) specimen MU146; Plesiastrea devantieri C) holotype MTQ G 55847 (Picture by P. Muir, MTQ), and D) specimen SO031; Montastraea curta E) syntype USNM 14 (Picture by the National Museum of Natural History, Smithsonian Institution), and F) specimen SO041; Goniastrea retiformis G) Holotype MNHN 86, and H) specimen BA077. Scale bars $=1 \mathrm{~cm}$. Grey filled arrows in inset of C show third order septa $\left(\mathrm{S}_{3}\right)$ in $P$. devantieri holotype.
Sampling in Mayotte took place in May 2010 during the third Reef leg of the Tara Oceans scientific expedition.

Digital images of living corals in the field were taken with a Canon G9 in an Ikelite underwater housing system. Coral specimens were collected, tagged, and for each specimen $1 \mathrm{~cm}^{2}$ was broken off the colony and preserved in absolute ethanol for further molecular analysis. The remaining corallum was placed for 48 hours in sodium hypochlorite to remove all soft parts, rinsed in freshwater and dried for microscope observation. Images of the cleaned skeletons were taken with a Canon G9 digital camera. 


\section{Specimen identification}

The material collected was identified referring to the genera and species descriptions and illustrations by Lamarck (1816), Dana (1846), Milne-Edwards and Haime (1848), Vaughan and Wells (1943), WijsmanBest (1976, 1977), Veron et al. (1977), Chevalier and Beauvais (1987), and Veron (2000, 2002). Moreover, the type specimens of Plesiastrea versipora (Fig. 1A), P. devantieri (Fig. 1C), Montastraea curta (Fig. 1E), and Goniastrea retiformis (Fig. 1G) were examined and their morphology compared with that of the material sampled for this study (Fig. $1 \mathrm{~B}, \mathrm{D}, \mathrm{F}$, and $\mathrm{H}$, respectively).

\section{Museum collections and other examined specimens}

Type material and specimens examined for this study are deposited in different institutes.

Abbreviations:

EPA Environment Protection Authority, Sana'a and Socotra, Yemen

IRD Institut de Recherche pour le Développement, Nouméa, New Caledonia

MNHN Muséum National d'Histoire Naturelle, Paris, France

MTQ Museum of Tropical Queensland, Townsville, Australia

SMF Senckenberg Museum, Frankfurt, Germany UNIMIB Università di Milano-Bicocca, Milan, Italy

USNM United States National Museum of Natural History, Washington, U.S.A.

The holotype of Plesiastrea devantieri (MTQ G 55847) was examined at the Museum of Tropical Queensland. The P. versipora specimens in the Lamarck and Milne-Edwards collections hosted at MNHN, including the species holotype, as well as the type material of Plesiastrea urvillei (MNHN 773), Astrea retiformis (MNHN 86), and Heliastrea annuligera MilneEdwards and Haime, 1848 (MNHN 674), were examined during a visit in October 2010. Images of the latter were kindly taken by A. Andouche (MNHN). The U.S Exploring Expedition specimens at the USNM were examined during a visit in July 2009. The illustration of the one of the syntypes of Astraea (Orbicella) curta (USNM 14) was provided with the permission of the National Museum of Natural History, Smithsonian Institution, (http://www.nmnh.si.edu/). Plesiastrea spp. and Cyathelia $\mathrm{cf}$ axillaris specimens in the SMF Socotra collection currently deposited at the Yemen EPA Socotra were studied in February 2010. The images of Trochocyathus efateensis were kindly provided by M. Kitahara (James Cook University).

\section{Morphological analyses}

Both macro and micromorphological characters (sensu Budd and Stolarski, 2009) of the two Plesiastrea species were examined using light microscopy (Zeiss Stemi DV4 stereo-microscope) and SEM, respectively. For SEM, specimens were mounted using silver glue, sputter-coated with conductive gold film and examined using a Vega Tescan Scanning Electron Microscope at the SEM Laboratory, University of MilanoBicocca.

\section{DNA extraction, amplification and sequencing}

Extraction of coral DNA was performed using DNeasy ${ }^{\circledR}$ Tissue kit (QIAGEN, Qiagen Inc., Valencia, CA, USA) according to the manufacturer's protocol. Each extracted sample was quantified using a Nanodrop 1000 spectrophotometer (Thermo Scientific) and diluted to a final DNA concentration of $3 \mathrm{ng} / \mu \mathrm{l}$. The mitochondrial gene COI and a portion of rDNA (spanning the entire ITS1, 5.8S, ITS2 and a portion of $28 \mathrm{~S}$ and $18 \mathrm{~S}$ ) were amplified and sequenced. COI and rDNA have been extensively used to reconstruct phylogenetic relationships among scleractinians corals (Odorico and Miller, 1997; Lam and Morton, 2003; Fukami et al., 2004, 2008; Moothien Pillay et al., 2006; Benzoni et al., 2007, 2010; Stefani et al., 2008; Huang et al., 2009; Kitahara et al., 2010b). The use of both markers allowed inference of the phylogeny at higher and lower systematic levels, due to their different evolutionary rates (Shearer et al., 2002; Chen et al., 2004; Wei et al., 2006; Huang et al., 2008). The mitochondrial marker was amplified using specific primers for Scleractinia, MCOIF (5' TCT ACA AAT CAT AAA GAC ATA GG 3') and MCOIR (5' GAG AAA TTA TAC CAA AAC CAG G 3') (Fukami et al., 2004). The $50 \mu 1$ PCR mix was composed of $1 X$ PCR buffer, $2 \mathrm{mM} \mathrm{MgCl}, 0.3 \mu \mathrm{M}$ for both of each primer, $0.01 \mathrm{mM}$ dNTP, $3 \mathrm{U}$ taq polymerase (Sigma-Aldrich Co., St. Louis, MO, USA) and $8 \mu$ of DNA solution. The thermal cycle consisted of an initial denaturation phase of $94^{\circ} \mathrm{C}$ for $2 \mathrm{~min}$ followed by 30 cycles composed of $94^{\circ} \mathrm{C}$ for $45 \mathrm{sec}, 55^{\circ} \mathrm{C}$ for $45 \mathrm{sec}, 72^{\circ} \mathrm{C}$ for 90 $\mathrm{sec}$, and finally an extension phase at $72^{\circ} \mathrm{C}$ for $5 \mathrm{~min}$. 

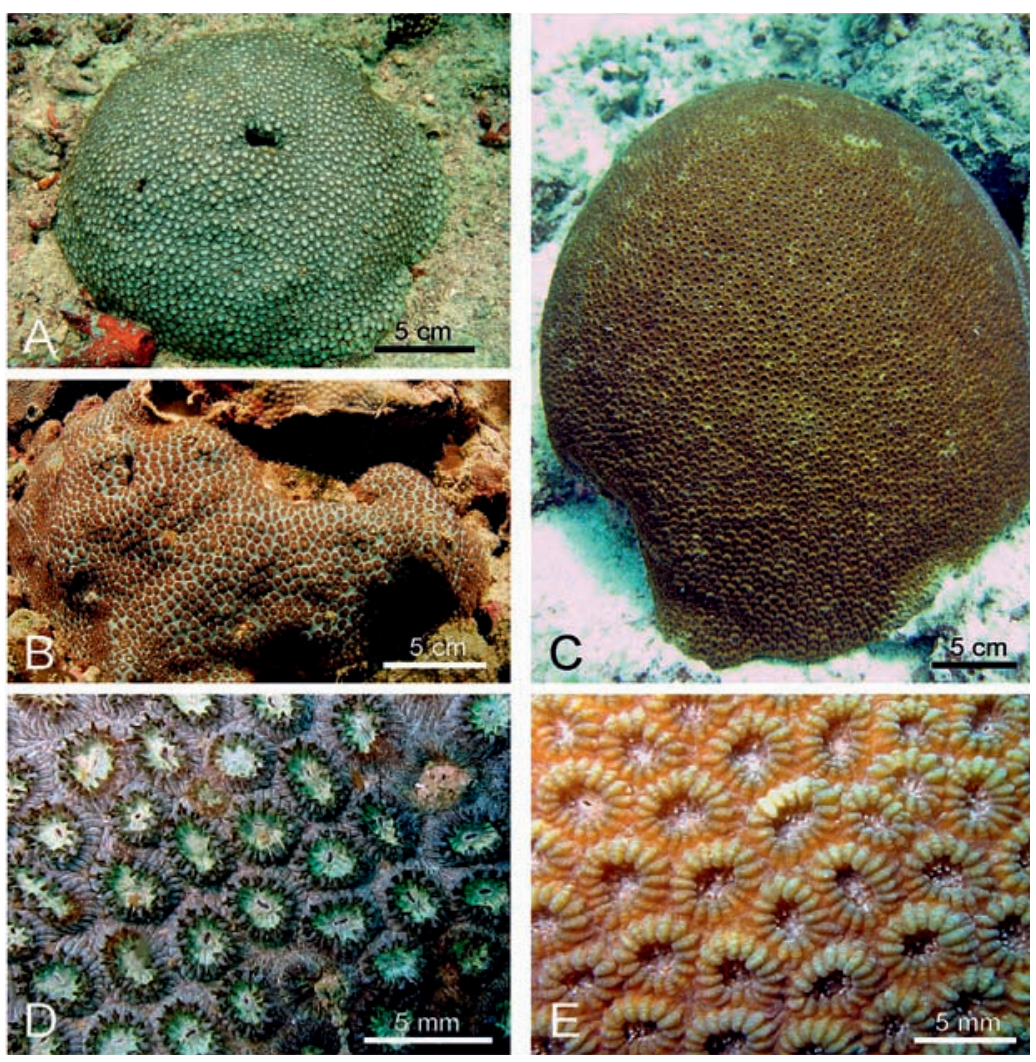

Fig. 2. In situ images of living colonies of: Plesiastrea versipora A) massive colony with typical green colouration, Kamaran Island, Yemen, $8 \mathrm{~m}$; B) encrusting colony with brown colouration, Balhaf, Yemen; Plesiastrea devantieri C) massive colony, Socotra Island, $10 \mathrm{~m}$. Close ups of the corallites of D) $P$. versipora with expanded polyps and E) $P$. devantieri.

Amplification of nuclear marker was performed using the coral-specific primer A18S (5' GAT CGA ACG GTT TAG TGA GG 3') (Takabayashi et al., 1998) and the universal primer ITS4 (5' TCC TCC GCT TAT TGA TAT GC 3') (White et al., 1990). Reactions were conducted with $1 \mathrm{X}$ PCR buffer, $2 \mathrm{mM} \mathrm{MgCl}_{2}, 0.4 \mu \mathrm{M}$ for both of each primer, $0.1 \mathrm{mM}$ dNTP, $2 \mathrm{U}$ taq polymerase (Sigma-Aldrich Co., St. Louis, MO, USA), 8 $\mu \mathrm{l}$ of DNA solution and water to $50 \mu \mathrm{l}$, using the protocol of $96^{\circ} \mathrm{C}$ for $2 \mathrm{~min}, 30$ cycles of $96^{\circ} \mathrm{C}$ for $10 \mathrm{sec}$, $50^{\circ} \mathrm{C}$ for $30 \mathrm{sec}, 72^{\circ} \mathrm{C}$ for $4 \mathrm{~min}$, ending with $72^{\circ} \mathrm{C}$ for 5 min. PCR products were sent to Macrogen Inc. (Seoul, South Korea) for further purification and sequencing.

\section{Phylogenetic analyses}

Chromatograms were manually checked using CodonCode Aligner 2.0.6 (CodonCode Corporation, Dedham, MA, USA). Sequences were aligned with BioEdit Sequence Alignment Editor 7.0.9.1 (Hall, 1999). Invariable, polymorphic and parsimony informative sites were detected with DnaSP 5.10.01 software (Librado and Rozas, 2009). Genetic distances and their standard deviation were calculated as p-distance with MEGA 4.0.2 software (Tamura et al., 2007). Phylogenetic inference was conducted using Bayesian Inference (BI) with MrBayes 3.1.2 (Huelsenbeck and Ronquist, 2001; Ronquist and Huelsenbeck, 2003), Maximum Likelihood (ML) using PhyML 3.0 (Guindon and Gascuel, 2003) and Maximum Parsimony (MP) based on PAUP* 4.0b10 (Swofford, 2003). For BI and ML analyses evolutionary models were assessed with Akaike Information Criterion (AIC) as implemented in MrModeltest 2.3 software (Nylander, 2004). As most suitable models AIC selected the $\mathrm{HKY}+\mathrm{I}+\Gamma$ for the mitochondrial marker (gamma=1.0033 and p-invar $=0.5341$ ) and the $\mathrm{GTR}+\mathrm{I}+\Gamma$ for the nuclear marker (gamma $=1.0079$ and $p$-invar $=0.2315)$. BI analysis consisted of four parallel Markov chains implemented for 10500000 generations for COI (1000000 generations for rDNA), saving a tree every 100 generations for both mitochondrial and nuclear markers and discarding the first 26251 trees as burn-in for COI (2501 for rDNA). For both markers BI analyses were stopped when the standard deviations of split frequencies were $<0.01$. The software Tracer 1.5 (Drummond and Rambaut, 2007) was also used in order to correctly estimate 
the burn-in and to verify the convergence. Best ML tree was obtained with PhylML (HKY85 model for COI and GTR model for rDNA, 4 substitution rate categories, setting the proportion of invariable sites and gamma distribution parameter to the values estimated with MrModeltest 2.3) using Shimodaira and Hasegawa (SH-like) test to check the support of each internal branch. MP analysis was performed using a heuristic search and the tree-bisection-reconnection branch swapping algorithm producing a strict consensus tree. Node supports were obtained with 500 bootstrap replicates in which the maximum number of trees was set to 40000 .

\section{Results}

\section{Macromorphology}

Plesiastrea versipora and $P$. devantieri share macromorphological traits such as a flattened to massive colony (Fig. 2A-C), plocoid corallite arrangement (Fig. 1A-D, 2D-E), the presence of three orders of laminar septa continuing over the wall as costae (Fig. 3, 4A-B) and well developed palar structures (Figs 3-4).

The two species can be distinguished, however, on the basis of several macro and micromorphological features (Table 2). Corallites are smaller in P. versipora (2 to $3.5 \mathrm{~mm}$ in diameter) (Fig. 1A-B) than in $P$. devantieri (3 to $5 \mathrm{~mm}$ in diameter) (Fig. 1C-D). Although both species have three cycles of septa $\left(\mathrm{S}_{1-3}\right)$ and well developed palar structures, their number and development is substantially different in the two taxa (Table 2). In $P$. versipora $\mathrm{S}_{1}$ (6 to 8 septa) and $\mathrm{S}_{2}$ (6 to 8 septa) can be equal (Fig. $3 \mathrm{~A}$ ), or $\mathrm{S}_{2}$ variably shorter than $S_{1}$ (Fig. 1A). Although in the holotype $S_{1}$ and $S_{2}$ can be 8 in most corallites (Fig. 1A), specimens bearing $6 \mathrm{~S}_{1}$ and $\mathrm{S}_{2}$ are commonly observed (Fig. 1A; [Figs. 284-292] Veron and Pichon, 1976). $S_{3}$ can be up to $1 / 4$ the length of $S_{1}$ (Fig. $3 \mathrm{C}$ ), or extremely reduced $\left(S_{1} \geq S_{2}>S_{3}\right) . S_{1}$ always reaches the columella, $S_{2}$ only if as developed $S_{1}$. Two crowns of pali $\left(\mathrm{P}_{1-2}\right)(12-16$ pali in total) are present between $\mathrm{S}_{1-2}$ and the columella (Figs 3A, C, 4A, C). $\mathrm{P}_{1}$ and $\mathrm{P}_{2}$ can be equal (Fig. 4C) or sub-equal (Veron et al., 1977) and are very variable in width and length (see Veron et al., 1977, p. 151, Figs. 284-292). $\mathrm{P}_{1-2}$ flush with, or slightly higher than, the corallite wall upper margin (Fig. 4A).

In $P$. devantieri $\mathrm{S}_{1}$ usually number 6 to 8 in mature corallites and reach the columella (Fig. 3B). In this species palar structures are actually paliform lobes, not pali, and number 8 in most corallites (Figs 3B, D, 4D). $\mathrm{S}_{2}$ are often incomplete, usually $1 / 4$ to $1 / 2$ of the first order in length. No paliform lobe development occurs between $\mathrm{S}_{2}$ and the columella (Fig. 3B, D). Occasionally,

Table 2. Morphological characters distinguishing Plesiastrea versipora from P. devantieri.

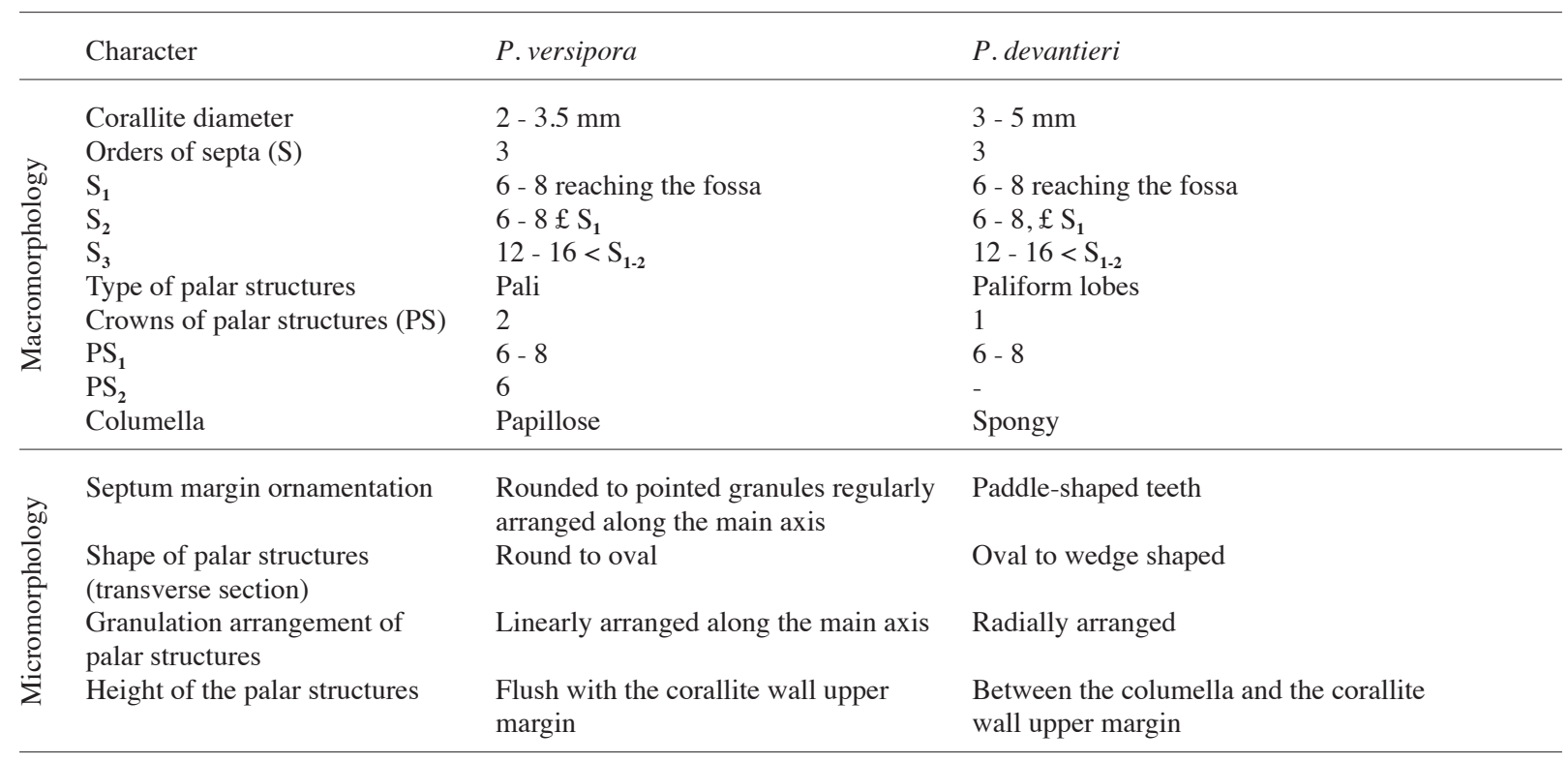



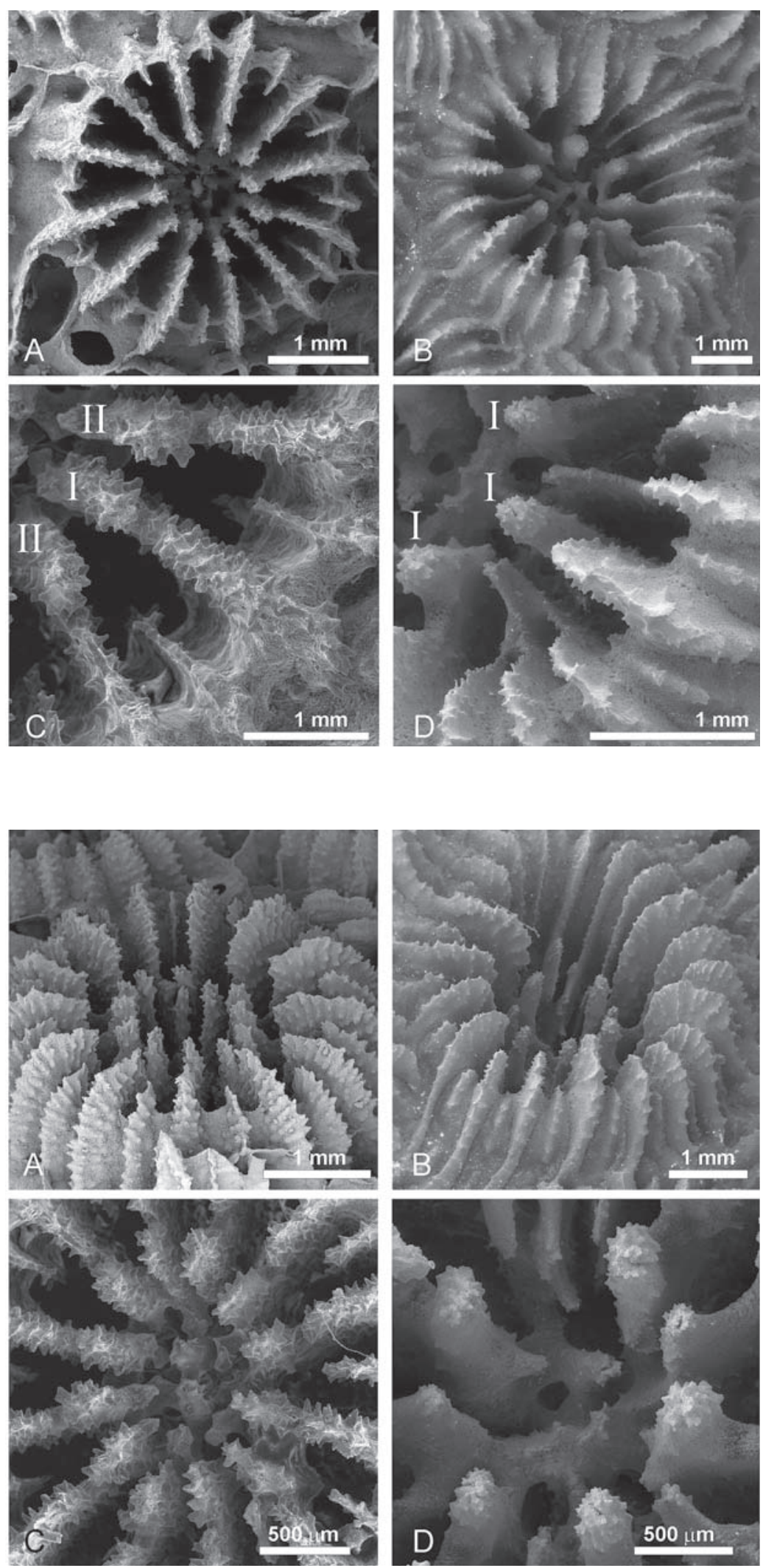

Fig. 3. Scanning Electron Micrograph of a corallite of A) Plesiastrea versipora (BA123) and of B) Plesiastrea devantieri (TOMAY053) showing septal arrangement. Details of septa and palar structures (PS) in C) $P$. versipora (MU146) and D) P. devantieri. I $=$ PS in front of first order septa; II = PS in front of second order septa.
Fig. 4. Scanning Electron Microscope side view of a corallite of A) Plesiastrea versipora (BA123) and of B) Plesiastrea devantieri (TO-MAY053) showing different height of the palar structures in the two species. Arrangement and shape of $\mathrm{C}$ ) pali $P$. versipora (BA123) and D) paliform lobes in P. devantieri. 
one or two longer secondary septa can almost reach the columella but these remain devoid of paliform lobes. Although not mentioned in the species original description, a third order of septa is also present in the holotype (inset in Fig. 1C) as well as in the rest of the examined material. $\mathrm{S}_{3}$ generally much reduced (Fig. 3B, D) and hard to detect with the naked eye (Fig. 1CD). Although Veron (2002) indicated in the P. devantieri original description that costae do not extend over the coenosteum in the holotype, this was observed in parts of the specimen, and in a number of specimens where the coenosteum between corallites is more developed costae show a tendency to extend over it (Fig. 1D). The paliform lobes between $S_{1}$ and the columella sit in the fossa, lower than the corallite wall upper margin level (Fig. 4B).

The columella in $P$. versipora is always well developed although small and papillose (Fig. 4C). In $P$. devantieri the columella is made of a few interwoven threads (Fig. 4D).

\section{Micromorphology}

SEM observations of septal micromorphology showed remarkable differences between the two examined species. In $P$. versipora minute, regularly spaced septal teeth are arranged along the septum direction (Fig. 5A, C). Conversely, in P. devantieri the typical paddle-like structures or fans described in the Atlantic Faviidae (Cuif and Perrin, 1999; Cuif et al., 2003) but not in the Pacific Faviidae (Budd and Stolarski, 2011) are observed (Fig. 5B, D). These distinct spiked ridges perpendicular to the septal plane (Budd and Stolarski, 2009) were also observed on the costae (Fig. 5B).

The septa centers of rapid accretion in $P$. versipora are formed by calcification axes inclining outwards from the centers of rapid accretion axis and producing a granulation pattern on the septal sides (Fig. 6A). The granules are arranged in vertical lines and the degree to which they protrude may vary between corallites and specimens (Fig. 3C) or less (Fig. 5A, C). In $P$. devantieri granulations on the septa sides are similar though less regularly arranged and the lines are further apart (Fig. 6B).

Finally, shape and ornamentation of the palar structures differ between $P$. versipora and $P$. devantieri. In $P$. versipora pali can be elongate to wedge-shaped in transverse section (Fig. 4C), their main axis following the same direction as the septum behind it. Granulations are regularly arranged along the palus main axis (Fig. 6A, C) in the same fashion as along the septum.
Paliform lobes in P. devantieri are round to oval in transverse section (Fig. 4D) and their ornamentation is star-like (Fig. 6B, D), closely resembling in shape and ornamentation the septal teeth formed by calcification axes in multiple directions as illustrated by Budd and Stolarski (2009, cf. Fig. 6) in the Mussidae.

\section{COI phylogeny}

Three specimens of Plesiastrea versipora and three of $P$. devantieri were sequenced and used for phylogenetic reconstruction, together with 51 sequences from clades XI to XXI delineated in Fukami et al. (2008) and other sequences from Kitahara et al. (2010b). In particular, the available sequences of Trochocyathus efateensis, Cyathelia axillaris and Plerogyra sp. were added. A sequence of Galaxea fascicularis (AB441201) was included as an outgroup. Finally, three sequences of Goniastrea retiformis and one of Montastraea curta from the Indian Ocean were also obtained during this study and added to the dataset.

The final alignment consisted of 580 positions. No indels were observed and a total of 185 polymorphic sites (112 informative) were identified. The phylogenetic trees obtained under the three criteria are largely congruent between each other and with the main available phylogenies. In detail, clades XII, XIII, XIV, XV, XVIII, and XXI sensu Fukami et al. (2008) are resolved. Clade XI is partially unresolved, due to the basal unresolved position of Oulastrea crispata. Clade XVII, also includes subclade XVIII. Finally, clade XIX and XX merged in a single clade. The phylogeny shows low resolution at genus and species levels, as extensive polytomies affect clade XVII in particular. The three examined specimens of $P$. devantier $i$ are not resolved within this main clade. Nevertheless, Plesiastrea versipora samples from the Gulf of Aden and the Indian Ocean cluster together with the other specimens from the Western Pacific, with C. axillaris, and T. efateensis in a sister clade, thus confirming the strong affinity between these genera as indicated by Kitahara $e t$ al. (2010b). Overall, the genus Plesiastrea results polyphyletic and a strong divergence between the two species ascribed to this genus is supported by the mitochondrial marker.

rDNA phylogeny

A total of three specimens of Plesiastrea versipora and three of $P$. devantieri were amplified, sequenced and used in the phylogenetic analysis. No intraindividual 

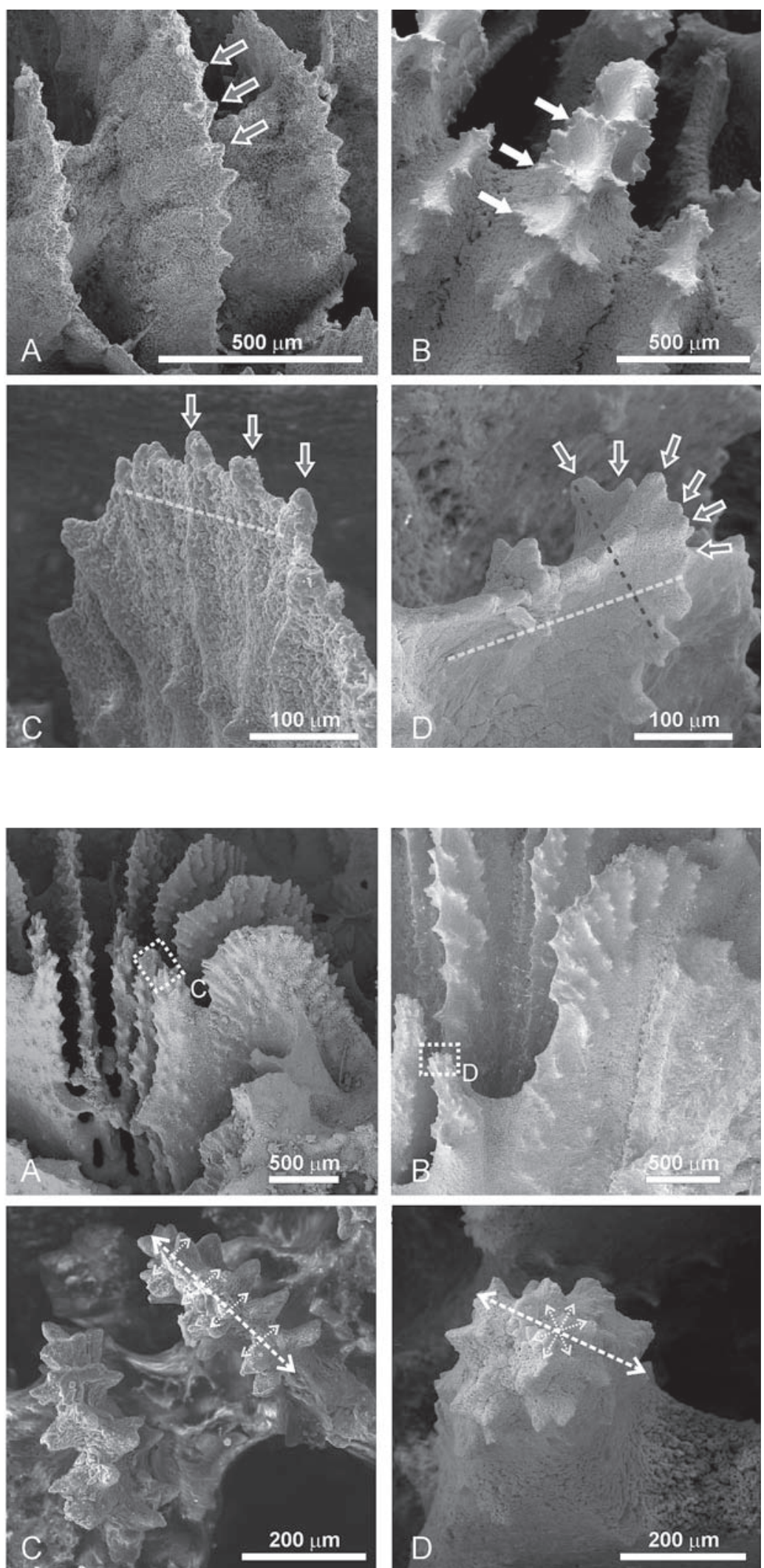

Fig. 5. Scanning Electron Microscope images of A, C) Plesiastrea versipora (MU146) and B, D) Plesiastrea devantieri (TOMAY053) septa showing different types of ornamentation in the two species. Grey filled arrows point at granules; white filled arrows point at paddle-shaped teeth; white dashed lines indicate the septal plane direction; grey dashed line indicates the paddle-shaped teeth main axis direction.
Fig. 6. Scanning Electron Microscope lateral views of septa and palar structures of A) Plesiastrea versipora (MU146) and B) Plesiastrea devantieri (TO-MAY053). White dotted insets indicate the position of elements shown in $\mathrm{C}$ and $\mathrm{D}$, respectively. Top view of C) two pali of $P$. versipora and D) one paliform lobe in $P$. devantieri showing different arrangement of granules in the two species. Larger dashed white arrows indicate the septal plane direction, smaller dashed grey arrows indicate the granules growth directions. 
polymorphisms were observed in the chromatograms. Although direct sequencing of rDNA in corals may hide some rare intra-individual variants (Vollmer and Palumbi, 2004), this loss of information may be relevant only in a limited number of cases in the Complex clade (Marquez et al., 2003; Vollmer and Palumbi, 2004; Chen et al., 2004), and direct sequencing prevents the risk of introducing PCR artefacts into the analysis, unlike methods using cloning (Bradley and Hillis, 1997; Flot et al., 2006).

The phylogenetic relationships between the obtained sequences and 42 other sequences, congruent with those employed for the mitochondrial phylogeny, were then inferred. Unfortunately, no sequences of $C$. axillaris or T. efateensis were available. Sequences of Goniastrea retiformis were obtained and included, together with the homolog and congeneric sequences of Goniastrea palauensis and Goniastrea aspera available in Genbank. The final alignment consisted of 763 bp, with 384 positions showing indels. A total of 177 polymorphic sites (127 parsimony informative) were detected.

The reconstructions obtained according to the three criteria are largely congruent. Minor variations are due to the lack of resolution in a few nodes shown by the MP analysis. Overall, the clades XI, XIV, XV sensu Fukami et al. (2008) detected in the mitochondrial tree are retained in the rDNA phylogeny, but here a higher resolution at species and genus levels is observed. Clades XIX and XX sensu Fukami et al. (2008) merge in a single clade, while clade XVIII form a subclade within the main XVII clade.

Plesiastrea versipora clusters with $P$. lichtensteini, thus supporting the relationships shown by the mitochondrial phylogeny. Plesiastrea devantieri falls within clade XVII, as seen in the COI phylogeny. A close affinity of $P$. devantier $i$ with a clade clustering together G.palauensis and G. aspera is shown. The type species of the genus Goniastrea, G. retiformis, groups together with Scapophyllia cylindrica and is more closely related to Montastraea curta and Platygyra sinensis than to the other two congeneric species.

\section{Discussion}

\section{Polyphyly of the genus Plesiastrea}

Plesiastrea versipora is a well known widely distributed Indo-Pacific species that has been recognised and identified for almost two centuries (inter alia Lamarck,
1816; Milne-Edwards and Haime, 1849; Yabe et al., 1936; Wells, 1954; Chevalier, 1971; Wijsman-Best, 1977; Veron et al., 1977; Scheer and Pillai, 1983; Carpenter et al., 1997; Veron, 2000; Pichon et al., 2010). The nomenclatural history of $P$. versipora is well summarised in Veron et al. (1977 [Figs 284-292]), together with a series of illustrations of the species morphological variability (see also Scheer and Pillai, 1983 [Plate 33, Figs 2-5]). The specimens examined in this study fall within the range of variability previously documented. Conversely, P. devantieri is a relatively newly described species recorded from Socotra and Madagascar (Veron, 2002). Only a few illustrations (Veron, 2000, 2002) and deposited specimens of $P$. devantieri are available. Sampling for this study in the type locality, as well as in another locality of the Indian Ocean, Mayotte (new geographic record for the species), provided material to evaluate the extent of intraspecific variability of certain characters and the stability of others. On the basis of the material examined there are superficial similarities between the two species. However, closer examination of the septal and palar macro and micromorphology together with molecular analyses using two independent markers indicates that $P$. versipora and $P$. devantieri are not phylogenetically closely related, and the latter shares more characters with the so-called 'Bigmessidae' (sensu Huang et al., 2011) than with Plesiastrea.

Our molecular results indicate a divergence level, expressed as p-distance, of $22.1 \pm 1.7 \%$ (mean \pm s.d.) for the rDNA marker and $5.4 \pm 0.9 \%$ for the COI marker. In the case of rDNA the divergence is comparable to the estimates obtained for some of the most polyphyletic and divergent genera, such as Montastraea and Platygyra (Wei et al., 2006). Also the p-distance obtained from the COI region is close to the upper distribution limit of confamilial divergences within the Scleractinia (Shearer and Coffroth, 2008).

From a morphological standpoint, the differences between $P$. versipora and $P$. devantieri are consistent and exceed the variation normally observed between closely related (i.e. congeneric) species of hard corals (i.e. variations in corallite diameter, length of septa, number of cycles of septa, number of septa in a cycle). Differences in the septal margin ornamentation and palar structures between these species support the nonmonophyly of the two taxa at the genus level.

The distribution of the calcification centres controls the septal external micro-morphology and the formation of teeth (Cuif and Perrin, 1999). In the Faviidae the teeth shape and structure, and the organization of 


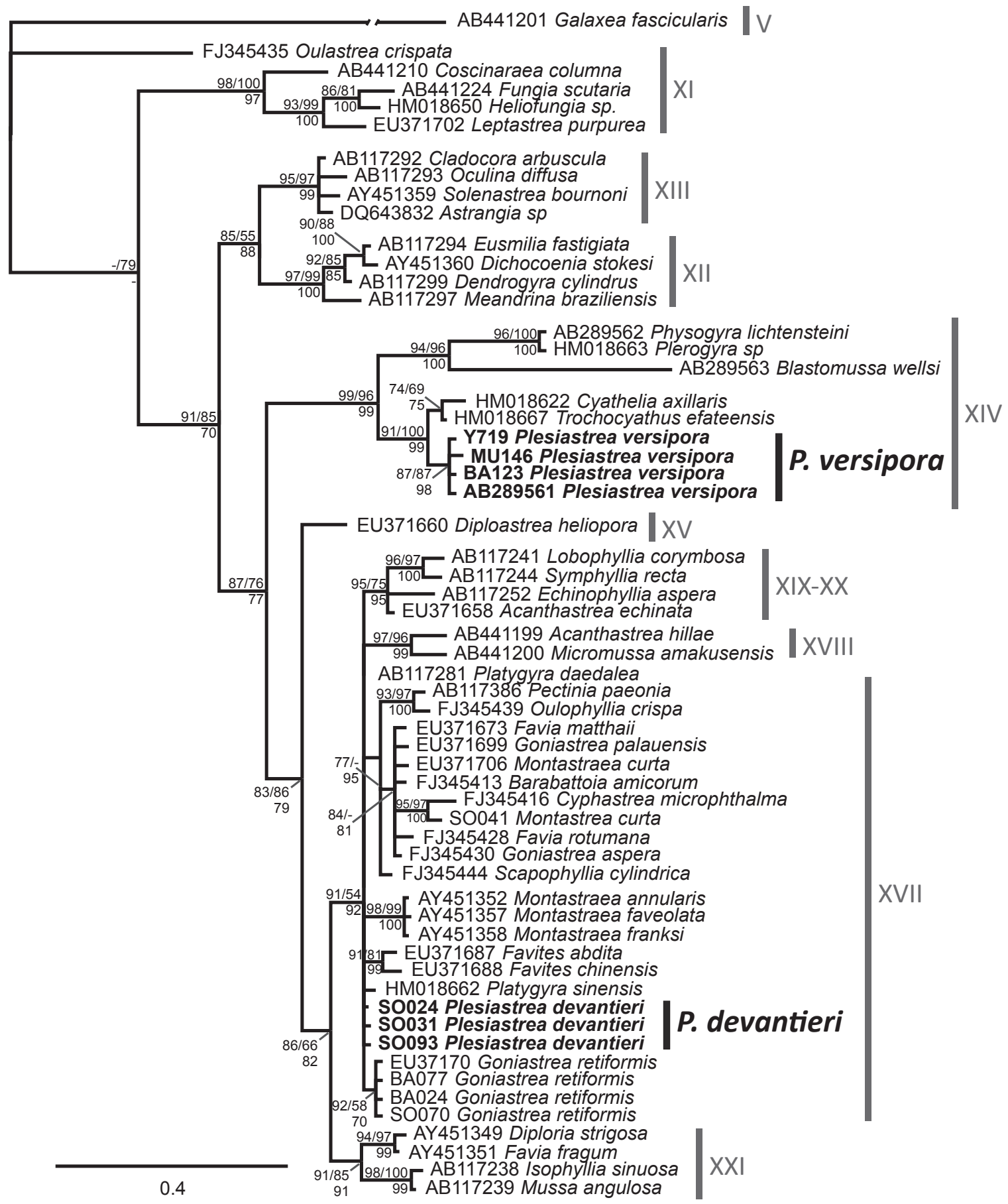

Fig. 7. Phylogenetic tree of mitochondrial gene COI reconstructed with Bayesian Inference. Maximum Likelihood and Maximum parsimony detected similar topologies. Numbers at each node show percentages of (above) Sh-like support ( $>70 \%$ ), and MP bootstrap $(>50 \%)$, and (below) Bayesian posterior probability $(>70 \%) ;-=$ no support. Clades of Plesiastrea versipora and Plesiastrea devantieri are in bold. Clade numbers refer to the same clades previously identified by Fukami et al. (2008). 


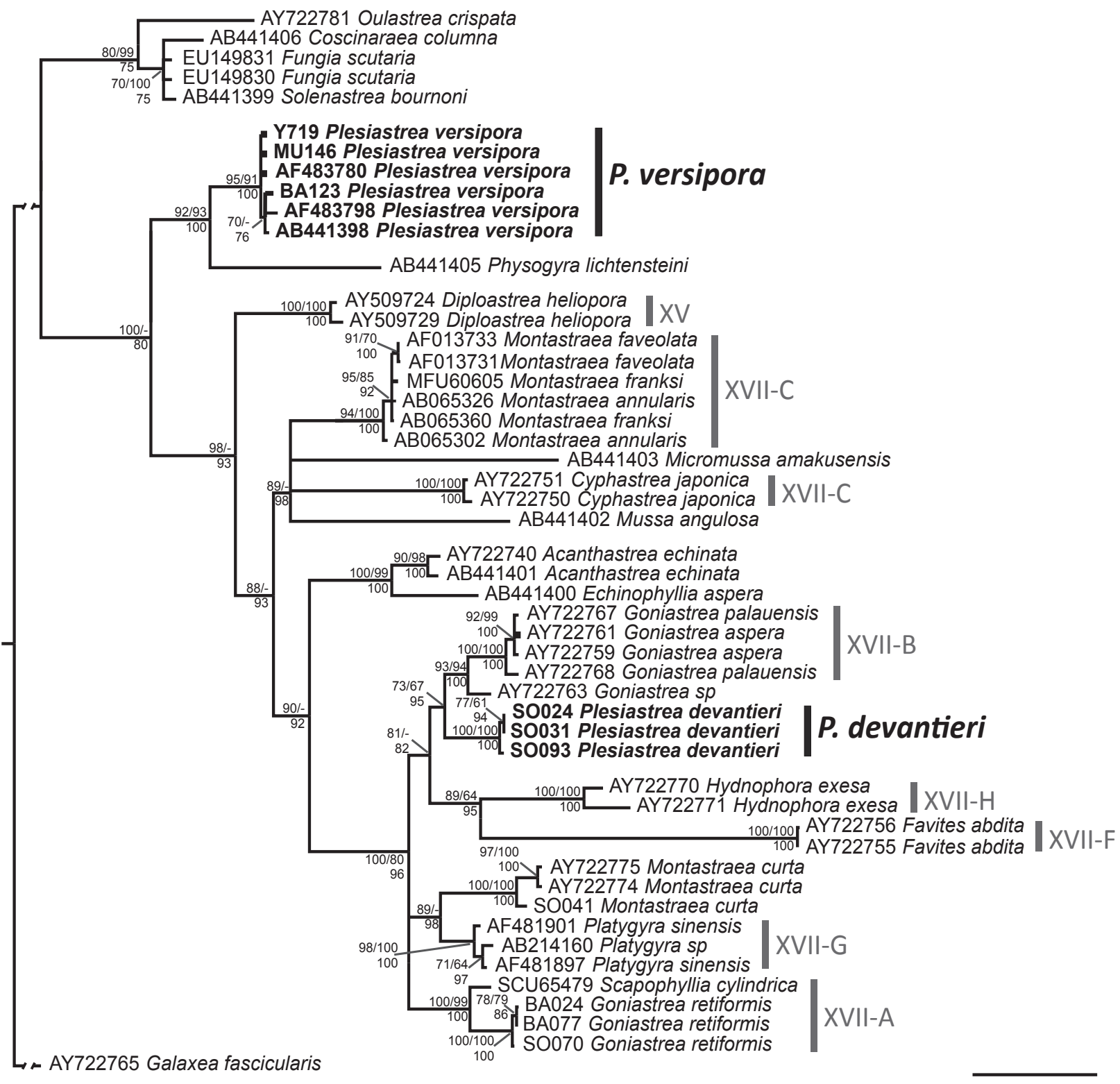

Fig. 8. Phylogenetic tree of a portion of rDNA (spanning the entire ITS1, 5.8S, ITS2 and a portion of 28S and 18S) reconstructed with Bayesian Inference. Maximum Likelihood and Maximum Parsimony detected similar topologies. Numbers at each node show percentages of (above) SH-like support ( $>70 \%$ ), and MP bootstrap ( $>50 \%$ ), and (below) Bayesian posterior probability $(>70 \%)$; - = no support. Clades of Plesiastrea versipora and Plesiastrea devantieri are in bold. Clade codes refer to the same sub-clades previously identified by Huang et al. (2011). 
the granules are variable and different between Atlantic and Pacific taxa (Budd and Stolarski, 2011). In the Atlantic Faviidae the septal calcification centres are arranged in clusters giving typical 'paddle-shaped' teeth (Figs 4-6 in Cuif and Perrin, 1999; Budd and Stolarski, 2011). Following the definition given by Budd and Stolarski (2009) 'a paddle-shaped tooth is formed by a short series of calcification centres (a secondary calcification axis) that is transverse to the direction of the septal plane'. Paddles are separated by short septal zones in which centres occur in the median septal plan. In the Pacific Faviidae septal teeth are multidirectional, more irregular and spine-like or 'lacerate' (Budd and Stolarski, 2011 [Fig. 2]). In P. versipora septal teeth are regularly arranged along the septum direction. In this species, the septal ornamentation and micro-structure are devoid of septal paddles, and similar to that described by Cuif et al. (2003) for Cladocora caespitosa, another taxon previously included by some authors in the Faviidae and currently in need of revision. Conversely, paddle-shaped teeth like those described in the Atlantic Faviidae were observed in Plesiastrea devantieri, an Indian Ocean species recovered within clade XVII. Although this may seem surprising, Favia stelligera, a Pacific faviid also found in clade XVII, sometimes has discrete centers of rapid accretion as well (Budd and Stolarski, 2011).

As remarked by several authors (Vaughan and Wells, 1943; Wells, 1954; Veron et al., 1977; Chevalier and Beauvais, 1987), it is not always easy to differentiate between pali and paliform lobes. They are ontogenetically and structurally different. Pali are defined as vertical structures developed along the inner axial margin of certain entosepta (Wells, 1956) and structurally identical to them. They are formed as the result of a substitution process of certain exosepta during the formation of entosepta (Wells, 1956 [Figs. 238, 241]) and composed of divergent centers of rapid accretion (or trabeculae in Chevalier and Beauvais, 1987 [Figs. 322A, 332F]). Paliform lobes are the result of the detachment of offsets of the centers of rapid accretion from the inner edge of certain septa (Wells, 1956) and are formed from a single simple or compound center of rapid accretion (Chevalier and Beauvais, 1987 [Fig. 322C]). In practical terms, however, the distinction is not straightforward. For example, the genus Goniastrea typically presents a well developed crown of palar structures. According to Wells (1956) these should be referred to as paliform lobes. However, Chevalier and Beauvais (1987) call these pali. Moreover, microstructural analyses have revealed that similar palar morphologies are structurally different (e.g. between the genus Goniastrea and Montastraea) (Budd and Stolarski, 2011). The palar structures in $P$. devantieri described as paliform lobes by Veron (2000) and as pali (Veron, 2002) and observed in the holotype as well as in the other specimens examined are similar to the paliform lobes typically found in the genera $\mathrm{Fa}$ via and Montastraea rather than the pali observed in $P$. versipora (Milne-Edwards and Haime, 1851; Vaughan and Wells, 1943; Chevalier and Beauvais, 1987).

Micro-structural and molecular data provided concordant evidence indicating that $P$. devantieri is closer to, inter alia, the genera Montastraea, Goniastrea and Favia, rather than $P$. versipora. In other words, $P$. devantieri is a valid species which does not belong to the genus Plesiastrea. In addition P. versipora is morphologically and genetically distant from the Faviidae and monophyletic with two apparently very different taxa, Cyathelia axillaris and Trochocyathus efateensis. Both statements require further discussion and are addressed hereafter.

\section{Phylogenetic relationships of Plesiastrea versipora}

On the basis of macro and microstructural features, Plesiastrea versipora is clearly distinct from the rest of the taxa presenting typical faviid micromorphology, including, as discussed, P. devantieri. Thus, the results of the species macro and micromorphology substantiate the previously published molecular results indicating that $P$. versipora is not closely related to the 'traditional' family Faviidae. What remains to be explained, at least from a morphological standpoint, is the strongly supported clade including $P$. versipora (formerly Faviidae), Cyathelia axillaris (traditionally Oculinidae) and Trochocyathus efateensis (traditionally Caryophylliidae) (Kitahara et al., 2010b).

It is not surprising that molecular phylogenies recover well supported clades including taxa with very different corallum organization and ecology (Barbeitos et al., 2010). However, some clades are more readily interpretable than others. To date, perhaps the most obvious case of a monophyletic group of Scleractinia including solitary and colonial, zooxanthellate and azooxanthellate, tropical and temperate, shallow and deep species is that of the Dendrophylliidae Gray 1847. This family, however, is well characterised by a number of skeletal characters supporting the monophyly of this well studied group (Cairns, 2001). Conversely, the morphological characters shared by other strongly supported clades including unexpectedly 
closely related taxa such as the one including $P$. versipora, C. axillaris, and T. efateensis, are less immediate.

Although one of the main goals of this study was to evaluate the monophyly of Plesiastrea rather than to examine in detail the morphologic affinities between this genus and Trochocyathus and Cyathelia, some macro morphologic features of the three genera (Fig. 9) are perhaps worth discussing in light of their close phylogenetic relationships (Kitahara et al., 2010b). The three taxa are strikingly different in terms of corallum condition and organization: solitary and cyathiform in Trochocyathus (Fig. 9A), colonial and encrusting to massive in Plesiastrea (Fig. 9B), and colonial and dendroid formed by regular and alternate budding in Cyathelia (Fig. 9C). Corallites of T. efateensis generally present 5 cycles of septa $\left(\mathrm{S}_{1-2}>\mathrm{S}_{3}>\mathrm{S} 4>\mathrm{S}_{5}\right)$ (Cairns, 1999), those of C. axillaris $4\left(\mathrm{~S}_{1-2}>\mathrm{S}_{3}>\mathrm{S}_{4}\right)$ (Cairns, 1994), and of $P$. versipora $3\left(\mathrm{~S}_{1} \geq \mathrm{S}_{2}>\mathrm{S}_{3}\right)$ (Veron et al., 1977; Wijsman-Best, 1976). From an ecological point of view, while both $T$. efateensis and $C$. axillaris are azooxanthellate deep water corals, $P$. versipora is a zooxanthellate reef dwelling species. However, the latter is also well known for being well adapted to high latitude environments (Kevin and Hudson, 1979; Veron et al., 1977; Rodriguez-Lanetty and Hoegh-Guldberg, 2002; Thomson and Frisch, 2010), to conditions of extreme temperature variations as in the Gulf (Carpenter et al., 1997; Burchard, 1979), and to the pseudo-high latitude conditions caused by cold water upwelling (Pichon et al., 2010).
Besides the presence of a papillose columella and well developed costae, the main character shared by $P$. versipora, C. axillaris, and T. efateensis is the number and disposition of discrete crowns of pali with respect to the number of cycles of septa (Vaughan and Wells, 1943; Chevalier and Beauvais, 1987; Cairns, 2004). In these species pali are well developed in front of each septal cycle before the last following the rule given by Milne-Edwards and Haime (1848) for the genus Plesiastrea ('Des pali bien développés devant tous les cycles cloisonnaires qui précèdent le dernier'). In Plesiastrea $\mathrm{P}_{1}$ and $\mathrm{P}_{2}$ can be more (Fig. 284 in Veron et al., 1977) or less (Fig. 3A, 4C) differentiated as also remarked by Milne-Edwards and Haime (1851) ('ceux [pali] des secondaires un peu plus larges et un peu moins rapprochés du centre que ceux des primaires'). Overall, a comparison of the corallites of $P$. versipora with well developed and sub-equal pali with the corallites of the other two closely related taxa does indeed suggest similarities between the three species (Fig. 9D, E, F).

As mentioned above, pali are usually interpreted as the result of the substitution of exosepta during the formation of entosepta (Wells, 1956 [Fig. 238]). This process explains their disposition in corals where those are only found in front of the penultimate cycle of septa, such as in the genus Caryophyllia Lamarck, 1816, and most of its close allies (Kitahara et al., 2010a, b). However, it does provide a satisfactory explanation in the case of corals with pali in front of each
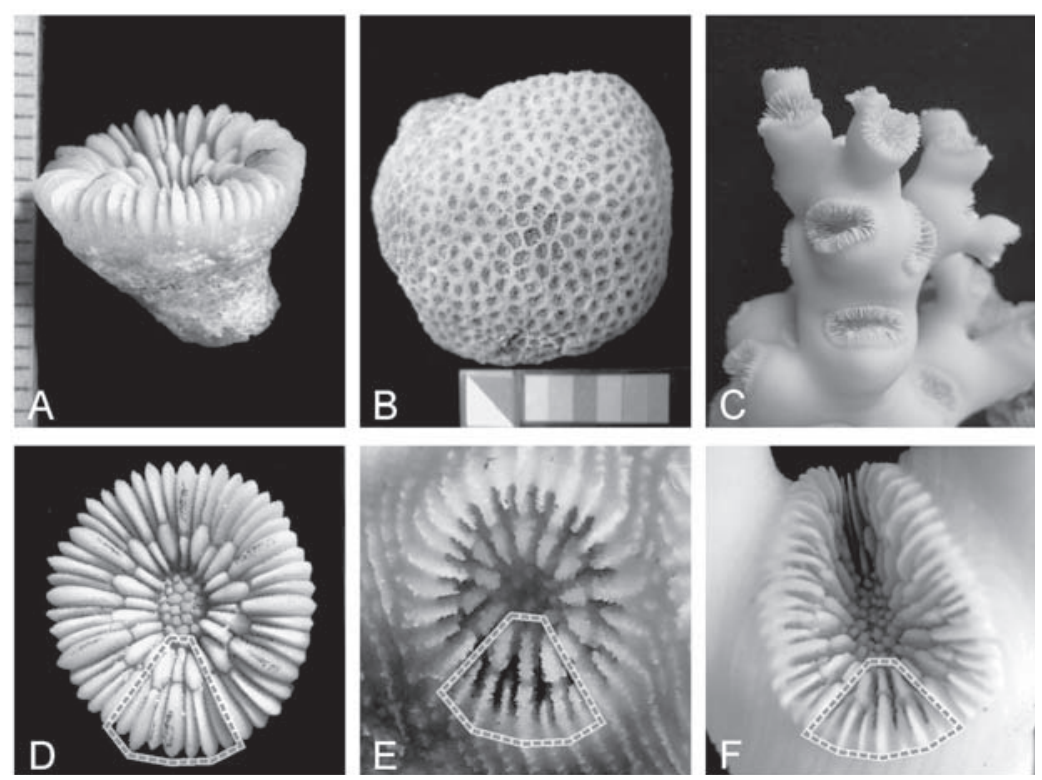

Fig. 9. Coralla of Trochocyathus efateensis [A) side view; D) top view, images kindly provided by Marcelo V. Kitahara], Plesiastrea versipora $[\mathrm{B})$ whole colony of the Holotype MNHN 36; E) detail of a corallite (AD021)], and Cyathelia axillaris [C) ramified colony (SMF C318S at EPA Socotra); F) detail of a corallite of the same specimen]. Dashed polygons in D, E, and F contour similar septa and pali arrangement in $T$. efateensis, $P$. versipora, and $C$. axillaris, respectively. 
septal cycle except for the last. In fact, the substitution model calls for a number of crown of pali equal to the number of cycles of exosepta minus one (Wells, 1956), and, hence, it would not be possible to find a crown of pali in front of $\mathrm{S}_{1}$. Rather, a second model of formation of pali described by Cuif (1968) and Chevalier and Beauvais (1987) seems to apply to the corals with pali in front of each septal cycle except for the last. According to this model, pali are produced by successive isolation from the septa inner margin, regardless of their ento or exocoelic nature, and acquisition of a system of divergent centers of rapid accretion. A different model involving a change of pali position with the formation of new septa was also proposed by LacazeDuthiers (1897).

Further analyses are needed to determine the relationship between Plesiastrea, Cyathelia, and Trochocyathus, and possibly other taxa, on the one hand, and to clarify if further morphologic affinities can be found in the septal micromorphology on the other hand. For example, Kitahara et al. (2010a) have proposed that, on the basis of 16S rDNA, Trochocyathus and Tethocyathus Kühn, 1933, may be sister genera. If this was confirmed, then another deep water taxon characterised by pali in front of each septal cycle before the last would be part of the Plesiastrea-Cyathelia-Trochocyathus clade. A new family would perhaps have to be described. However, other genera following the same plan may well not be closely related to Plesiastrea, and, hence, additional morphological characters will have to be considered.

Phylogenetic relationships of Plesiastrea devantieri and implications for taxonomy

According to the rDNA phylogeny in this study Plesiastrea devantieri is closely related to Goniastrea aspera Verrill, 1905 and G. palauensis (Yabe, Sugiyama \& Eguchi, 1936). However, COI results indicate that its position is unresolved in a clade including most of the Pacific faviids. Although similarities between Plesiastrea and Montastraea have been discussed at length in the literature, and despite the fact that a few authors have also indicated similarities with Favia, no author has gone as far as discussing similarities between Plesiastrea and Goniastrea.

From purely morphologic standpoint, the taxa looking closest to $P$. devantieri would be some species in the genus Montastraea, such as M. curta (Fig. 1E-F) and $M$. annuligera. Phylogenetic relationships between $P$. devantieri and the former species have been investigated in this study and revealed that the two taxa are not closely related (Figs 7-8). Moreover, on the basis of the results by Huang et al. (2011) M. annuligera is more closely related to $M$. valenciennesi and different species of Favia, rather than to G. aspera and G. palauensis. Finally, the genus Montastraea is deeply polyphyletic and awaiting formal taxonomic revision (Huang et al., 2011).

One of the long-standing paradigms of coral taxonomy and systematics is that cerioid and plocoid corallite arrangement are informative characters (Wells, 1956). Although both $P$. devantieri and Goniastrea spp. are characterized by well developed crowns of paliform lobes, the plocoid condition of the former, the cerioid condition of the latter, and the different mode of calicinal budding would not have suggested phylogenetic affinities. A revision of the genus Goniastrea does require a separate study. However, on the basis of both molecular phylogenies presented in this study, as well as in previous studies by Huang et al. (2009, 2011), the genus Goniastrea is not monophyletic, and the type species of the genus, G. retiformis, is not closely related to the two Goniastrea species which are closest to P. devantieri, namely G. aspera and G. palauensis. Instead, G. retiformis is closely related to $S c a$ pophyllia cylindrica (Milne-Edwards and Haime, 1848). Thus, while it has been shown in the present study that $P$. devantieri can no longer be assigned to the genus Plesiastrea, and that it should be included into the molecularly defined clade XVII (sensu Fukami et al., 2008), its assignation to a different genus is not a straightforward nomenclatural process. Until a complete revision of the Robust clade, or, at least, of clade XVII, is performed and phylogenetic relationships are fully understood, the taxonomic position of $P$. devantieri remains incertae sedis.

It is likely that once more taxa are added to the existing molecular phylogenies of the Scleractinia, more cases of monophyletic and well supported clades of taxa with very different morphologies will be discovered. Then, once more, the quest for evolutionarily informative characters, most likely to be found or rediscovered at the skeleton micro rather then the macro scale, will be open.

\section{Acknowledgements}

The authors are grateful three anonymous reviewers for their help and constructive comments. We wish to thank E. Dutrieux (CREOCEAN), C.H. Chaineau (Total SA), R. Hirst and M. 
AbdulAziz (YLNG) for allowing and supporting our research in Yemen. Thanks to S. Basheen (Professional Divers Yemen), M.A. Ahmad and F.N. Saeed (EPA Socotra), C. Riva, S. Montano, and A. Caragnano (UNIMIB) for their help in different parts of field work. Sampling in Mayotte was possible thanks to the Tara Oceans scientific expedition and the OCEANS Consortium. We are grateful in particular to E. Karsenti (EMBL) for allowing reef research during the expedition, to $\mathrm{S}$. Kandels-Lewis (EMBL), and to Captain H. Bourmaud and the Tara crew in general, and to M. Oriot and J.J. Kerdraon in particular. We are also indebted to L. Bigot (ECOMAR) and R. Friederich (World Courier). We are grateful to P. Muir (MTQ) for reviewing the manuscript and for images of the holotype of $P$. devantieri. Thanks to A. Andouche (MNHN), S. Cairns (USNM), and M. Visentini Kitahara (JCU) for specimens images, and to P. Gentile (UNIMIB) for technical help with the SEM. We are grateful to E. Reynaud (Adéquation \& Développement) for kindly donating part of the laboratory instruments for this study.

\section{References}

Barbeitos MS, Romano SL, Lasker HR. 2010. Repeated loss of coloniality and symbiosis in scleractinian corals. Proceedings of the National Academy of Sciences 107: 11877-11882.

Benzoni F, Stefani F, Pichon M, Galli P. 2010. The name game: morpho-molecular species boundaries in the genus Psammocora (Cnidaria, Scleractinia). Zoological Journal of the Linnean Society 160: 421-456.

Benzoni F, Stefani F, Stolarski J, Pichon M, Mitta G, Galli P. 2007. Debating phylogenetic relationships of the scleractinian Psammocora: molecular and morphological evidences. Contributions to Zoology 76: 35-54.

Bradley RD, Hillis DM. 1997. Recombinant DNA sequences generated by PCR amplification. Molecular Biology and Evolution 14: 592-593.

Budd AF, Romano SL, Smith ND, Barbeitos MS. 2010. Rethinking the phylogeny of Scleractinian corals: a review of morphological and molecular data. Integrative and Comparative Biology 50: 411-427.

Budd AF, Stolarski J. 2009. Searching for new morphological characters in the systematics of scleractinian reef corals: comparison of septal teeth and granules between Atlantic and Pacific Mussidae. Acta Zoologica 90: 142-165.

Budd AF, Stolarski J. 2011. Corallite wall and septal microstructure in Scleractinian reef corals: comparison of molecular clades within the family Faviidae. Journal of Morphology 272: 66-88.

Burchard JE. 1979. Coral fauna of the Arabian Gulf. Dhahran: ARAMCO Environmental Affairs.

Cairns SD. 1994. Scleractinia of the Temperate North Pacific. Smithsonian Contributions to Zoology 557: 1-150.

Cairns SD. 1999. Cnidaria Anthozoa: deep-water azooxanthellate Scleractinia from Vanuatu, and Wallis and Futuna islands. Mémoires du Museum national d'Histoire naturelle de Paris 180: 31-167.

Cairns SD. 2001. A generic revision and phylogenetic analysis of the Dendrophylliidae (Cnidaria: Scleractinia). Smithsonian Contributions to Zoology 615: 1-75.
Cairns SD. 2004. The Azooxanthellate Scleractinia (Coelenterata: Anthozoa) of Australia. Records of the Australian Museum 56: 259-329.

Carpenter KE, Harrison PL, Hodgson G, Alsaffar AH, Alhazeem SH. 1997. The corals and reef fishes of Kuwait. Kuwait Institute for Scientific Research, Environmental Public Authority, Kuwait City.

Chen CA, Chang CC, Wei NV, Chen CH, Lein YT, Lin HE, Dai CF, Wallace CC. 2004. Secondary structure and phylogenetic utility of the ribosomal internal transcribed spacer 2 (ITS2) in scleractinian corals. Zoological Studies 43: 759-771.

Chevalier JP. 1971. Scléractiniaires de la Mélanésie française. Expédition française sur les récifs coralliens de la NouvelleCalédonie 5: 5-307.

Chevalier JP, Beauvais L. 1987. Ordre des Scléractiniaires XI systématique. Pp 679-764 in: Grassé PP, ed., Traité de Zoologie 3, Paris: Masson.

Cuif JP. 1968. Etude ontogénique de quelques Madréporaires Caryophyllidae actuels et fossiles. Mémoires du Muséum national d'Histoire naturelle de Paris 16(3): 101-156.

Cuif JP, Perrin C. 1999, Micromorphology and microstructure as expressions of scleractinian skeletogenesis in Favia fragum (Esper, 1795) (Faviidae, Scleractinia). Zoosystema 21: 1-20.

Cuif JP, Lecointre G, Perrin C, Tiller A, Tillier S. 2003. Patterns of septal biomineralization in Scleractinia compared with their 28S rRNA phylogeny. A dual approach for a new taxonomic framework. Zoologica Scripta 32: 459-473.

Dana JD. 1846. Zoophytes. United States Exploring Expedition during the years 1838-1842, under the command of Charles Wilkes, U.S.N., vol. 7. Philadelphia: C. Sherman.

De Blainville HM. 1830. Zoophytes. In: Dictionnaire des sciences naturelles, dans lequel on traitre méthodiquement des différents êtres de la nature, considérés soit en eux-mêmes, d'après l'état actuel de nos connoissances, soit relativement à l'utilité qu'en peuvent retirer la médecine, l'agriculture, le commerce et les arts. F. G. Levrault. Tome 60. Paris, Le Normat. Pp. 548, pls. 68 .

Drummond AJ, Rambaut A. 2007. 'BEAST: Bayesian evolutionary analysis by sampling trees.' BMC Evolutionary Biology 7: 214.

Flot JF, Tillier A, Samadi S, Tillier S. 2006. Phase determination from direct sequencing of length-variable DNA regions. Molecular Ecology Notes 6: 627-630.

Fukami H, Budd A, Paulay G, Solé-Cava A, Chen CA, Iwao K, Knowlton N. 2004. Conventional taxonomy obscures deep divergence between Pacific and Atlantic corals. Nature 427: 832-834.

Fukami H, Chen CA, Budd AF, Collins A, Wallace C, Chuang YY, Chen C, Dai CF, Iwao K, Sheppard C, Knowlton N. 2008. Mitochondrial and nuclear genes suggest that stony corals are monophyletic but most families of stony corals are not (order Scleractinia, class Anthozoa, phylum Cnidaria). PLoS ONE 3(9): e3222.

Guindon S, Gascuel O. 2003. A simple, fast, and accurate algorithm to estimate large phylogenies by Maximum Likelihood. Systematic Biology 52: 696-704.

Hall TA. 1999. BioEdit: a user-friendly biological sequence alignment editor and analysis program for Windows 95/98/ NT. Nucleic Acids Symposium Series 41: 95-98. 
Huang D, Licuanan WY, Baird AH, Fukami H. 2011. Cleaning up the 'Bigmessidae': Molecular phylogeny of scleractinian corals from Faviidae, Merulinidae, Pectiniidae and Trachyphylliidae. BMC Evolutionary Biology 11: 37.

Huang D, Meier R, Todd PA, Chou LM. 2008. Slow mitochondrial COI sequence evolution at the base of the metazoan tree and its implications for DNA barcoding. Journal of Molecular Evolution 66: 167-174.

Huang D, Meier R, Todd PA, Chou LM. 2009. More evidence for pervasive paraphyly in scleractinian corals: Systematic study of Southeast Asian Faviidae (Cnidaria; Scleractinia) based on molecular and morphological data. Molecular Phylogenetics and Evolution 50: 102-116.

Huelsenbeck JP, Ronquist F. 2001. MRBAYES: Bayesian inference of phylogenetic trees. Bioinformatics 17: 754-755.

Kevin KM, Hudson RCL. 1979. The role of zooxanthellae in the hermatypic coral Plesiastrea urvillei (Milne Edwards and Haime) from cold waters. Journal of Experimental Marine Biology and Ecology 36: 157-170.

Kitahara MV, Cairns SD, Miller DJ. 2010a. Monophyletic origin of Caryophyllia (Scleractinia, Caryophylliidae), with descriptions of six new species. Systematics and Biodiversity 8: 91-118.

Kitahara MV, Cairns SD, Stolarski J, Blair D, Miller DJ. 2010 b. A comprehensive phylogenetic analysis of the Scleractinia (Cnidaria, Anthozoa) based on mitochondrial CO1 sequence data. PLoS One 5: e11490.

Lacaze-Duthiers H. 1897. Faune du Golfe du Lion. Coralliaires, Zooanthaires, Sclérodermés. Archives de Zoologie Expérimentale et Générale 5:1-249.

Lam K, Morton B. 2003. Morphological and ITS1, 5.8S, and partial ITS2 ribosomal DNA sequence distinctions between two species of Platygyra (Cnidaria; Scleractinia) from Hong Kong. Marine Biotechnology 5: 555-567.

Lamarck JBP. 1816. Histoire naturelle des animaux sans vertèbres, vol. 2. Paris: Verdier.

Le Goff-Vitry MC, Rogers AD, Baglow D. 2004. A deep-sea slant on the molecular phylogeny of Scleractinia. Molecular Phylogenetics and Evolution 30: 167-177.

Librado P, Rozas J. 2009. DnaSP v5: A software for comprehensive analysis of DNA polymorphism data. Bioinformatics 25: 1451-1452.

Marquez LM, Miller DJ, MacKenzie JB, Van Oppen MJH. 2003. Pseudogenes contribute to the extreme diversity of nuclear ribosomal DNA in the hard coral Acropora. Molecular Biology and Evolution 20: 1077-1086.

Milne-Edwards M, Haime J. 1848. Recherches sur les polypiers; 4eme mémoire. Monographie des Astréides. Annales des Sciences Naturelles 10: 209-320.

Milne-Edwards M, Haime J. 1849. Recherches sur les polypiers; 4eme mémoire. Monographie des Astréides. Annales des Sciences Naturelles 12: 95-197.

Milne-Edwards M, Haime J. 1851. Recherches sur les polypiers; 6 eme mémoire. Monographie des fongides. Annales des Sciences Naturelles 15: 73-144.

Moothien Pillay KR, Asahida T, Chen CA, Terashima H, Ida H. 2006. ITS ribosomal DNA distinctions and the genetic structures of populations of two sympatric species of Pavona (Cnidaria: Scleractinia) from Mauritius. Zoological Studies 45: 132-144.
Nunes F, Fukami FH, Vollmer SV, Norris RD, Knowlton N.2008. Re-evaluation of the systematics of the endemic corals of Brazil by molecular data. Coral Reefs 27: 423-432.

Nylander JAA. 2004. MrModeltest v2. Program distributed by the author. Evolutionary Biology Centre, Uppsala University.

Odorico DM, Miller DJ. 1997. Variation in the ribosomal internal transcribed spacers and 5.8S rDNA among five species of Acropora (Cnidaria; Scleractinia): patterns of variation consistent with reticulate evolution. Molecular Biology and Evolution 14: 465-473.

Pichon M, Benzoni F, Chaineau CH, Dutrieux E. 2010. Field guide of the hard corals of the southern coast of Yemen. Biotope, Paris.

Rodriguez-Lanetty M, Hoegh-Guldberg O. 2002. The phylogeography and connectivity of the latitudinally widespread scleractinian coral Plesiastrea versipora in the Western Pacific. Molecular Ecology 11: 1177-1189.

Romano SL, Cairns SD. 2000. Molecular phylogenetic hypotheses for the evolution of scleractinian corals. Bulletin of Marine Science 67: 1043-1068.

Romano SL, Palumbi RS. 1996. Evolution of Scleractinian corals inferred from molecular systematics. Science 271: 640642.

Ronquist F, Huelsenbeck JP. 2003. MrBayes 3: Bayesian phylogenetic inference under mixed models. Bioinformatics 19: $1572-1574$.

Scheer G, Pillai CSG. 1983. Report on the stony corals from the Red Sea. Zoologica 133: 1-198.

Shearer TL, Coffroth A. 2008. Barcoding corals: limited by interspecific divergence, not intraspecific variation. Molecular Ecology 8: 247-255.

Shearer TL, Van Oppen MJH, Romano SL, Wörheide G. 2002. Slow mitochondrial DNA sequence evolution in the Anthozoa (Cnidaria). Molecular Ecology 11: 2475-2487.

Stefani F, Benzoni F, Pichon M, Mitta G, Galli P. 2008. Genetic and morphometric evidence for unresolved species boundaries in the coral genus Psammocora (Cnidaria; Scleractinia). Hydrobiologia 596: 153-172.

Stolarski J. 2003. Three-dimensional micro- and nanostructural characteristics of the scleractinian coral skeleton: a biocalcification proxy. Acta Palaeontologica Polonica 48: 497-530.

Swofford DL. 2003. PAUP* Phylogenetic Analysis Using Parsimony (*and Other Methods). Version 4b.10. Sunderland MA: Sinauer Associates.

Takabayashi M, Carter DA, Loh WKT, Hoegh-Guldberg O. 1998. A coral-specific primer for PCR amplification of the internal transcribed spacer region in ribosomal DNA. Molecular Ecology 7: 925-931.

Tamura K, Dudley J, Nei M, Kumar S. 2007. MEGA4: Molecular Evolutionary Genetics Analysis (MEGA) software version 4.0. Molecular Biology and Evolution 24: 1596-1599.

Thomson DP, Frisch AJ. 2010. Extraordinarily high coral cover on a nearshore, high-latitude reef in south-west Australia. Coral Reefs 29: 923-927

Vaughan TW and Wells JW. 1943. Revision of the sub-orders, families and genera of the Scleractinia. Geological Society of America Special Papers 44, 363 pp.

Veron JEN, Wijsman-Best M, Pichon M. 1977. Scleractinia of Eastern Australia, II: Families Faviidae, Trachyphylliidae. Australian Institute of Marine Science Monograph Series 3: 1-227. 
Veron JEN. 2000. Corals of the world. Australian Institute of Marine Science, Townsville.

Veron JEN. 2002. New species described in corals of the world. Townsville: Australian Institute of Marine Science Monograph Series 11.

Vollmer SV, Palumbi SR. 2004. Testing the utility of internally transcribed spacer sequences in coral phylogenetics. Molecular Ecology 13: 2763-2772.

Wei NV, Wallace CC, Dai CF, Moothien Pillay KR, Chen CA. 2006. Analyses of the ribosomal internal transcribed spacers (ITS) and the $5.8 \mathrm{~S}$ gene indicate that extremely high rDNA heterogeneity is a unique feature in the scleractinian coral genus Acropora (Scleractinia; Acroporidae). Zoological Studies 45: 404-418.

Wells JW. 1954. Recent corals of the Marshall Islands. US Geologial Survey Prof Papers 260: 385-486.

Wells JW. 1956. Scleractinia. Pp. F328-F444 in: Moore RC, ed., Treatise on Invertebrate Paleontology, Part F: Coelenterata. Lawrence: University of Kansas Press.

White TJ, Bruns T, Lee S, Taylor J. 1990. Amplification and direct sequencing of fungal ribosomal RNA genes for phylogenetics. Pp. 315-322 in: Innis MA, Gelfand DH, Sninsky JJ,
White TJ, eds, PCR Protocols. A Guide to Methods and Application. San Diego, CA: Academic Press Inc.

Wijsman-Best M. 1976. Biological results of the Snellius expedition: XXVII. Faviidae collected by the Snellius expedition. II. The genera Favites, Goniastrea, Platygyra, Oulophyllia, Leptoria, Hydnophora and Caulastrea. Zoologische Mededelingen 50: 45-63.

Wijsman-Best M. 1977. Indo-Pacific coral species belonging to the subfamily Montastreinae Vughan and Wells, 1943 (Scleractinea-Coelenterata) Part I. The genera Montastrea and Plesiastrea. Zoologische Mededelingen 55: 235-263.

Yabe H, Sugiyama T, Eguchi M. 1936. Recent reef-building corals from Japan and the South Sea islands under the Japanese mandate. Science Reports of the Tohoku Imperial University, Sendai, Japan 1: 1-66.

Received: 17 March 2011

Revised and accepted: 15 June 2011

Published online: 30 September 2011

Editor: R.W.M. van Soest 
